\title{
Challenges of an unusual Osteoradionecrosis of the jaws: case report
}

\author{
Desafios de Osteorradionecrose incomum dos ossos maxilares: relato de caso \\ Desafíos de una Osteorradionecrosis inusual de los maxilares: reporte de un caso
}

Received: 08/20/2021 | Reviewed: 08/25/2021 | Accept: 08/25/2021 | Published: 08/27/2021

\author{
Susiane Silva de Sousa ${ }^{1}$ \\ ORCID: https://orcid.org/0000-0001-8621-0831 \\ State University of Bahia, Brazil \\ E-mail: susiane_sousa@yahoo.com.br \\ Bruno Antônio Veloso Cerqueira ${ }^{2}$ \\ ORCID: https://orcid.org/0000-0001-8839-1787 \\ State University of Bahia, Brazil \\ E-mail: brunoveloso2@hotmail.com \\ Antônio Lucas Castro Pimentel ${ }^{3}$ \\ ORCID: https://orcid.org/0000-0002-7404-8758 \\ Bahiana School of Medicine and Public Health, Brazil \\ E-mail: brunoveloso2@hotmail.com \\ Juliana Borges de Lima Dantas ${ }^{4}$ \\ ORCID: https://orcid.org/0000-0002-9798-9016 \\ Federal University of Bahia, Brazil \\ Bahiana School of Medicine and Public Health, Brazil \\ E-mail: julianadantas@bahiana.edu.br \\ Antônio Márcio Teixeira Marchionni ${ }^{5}$ \\ ORCID: https://orcid.org/0000-0003-1701-046X \\ Bahiana School of Medicine and Public Health, Brazil \\ E-mail: marchionni@uol.com.br \\ Alena Ribeiro Alves Peixoto Medrado 6 \\ ORCID: https://orcid.org/0000-0003-4074-4680 \\ Federal University of Bahia, Brazil \\ E-mail: armedrado@ufba.br
}

\begin{abstract}
Osteoradionecrosis (ORN) is the most worrying radiotherapy late complication. It is a condition in which the irradiated bone becomes devitalized and exposed through fistulas in the skin or mucosa. It remains without healing for a period of at least three months. Despite being a well-known entity to the professionals who treat neoplasms of the head and neck, the disease has many controversies. From its classifications to its best treatment plan. Its main signs and symptoms are pain, drainage of secretion, fistulas, ulcers of the oral mucosa, bone exposure, bone necrosis, and the surrounding soft tissue. This study aims to report a clinical case of a patient with ORN in the jaw treated at Bahiana School of Medicine and Public Health and the General Roberto Santos Hospital. A 60-year-old-male patient with a malignant neoplasm in the tonsil region, was diagnosed with ORN in mandible region, three years after radiotherapy. The treatment proposal was conservative (ozone therapy, hyperbaric oxygen and chlorexidine mouth rinse) associated with surgical debridement, with good results that involved the patient's rehabilitation. It is concluded that the association of conservative therapies with surgery demonstrated satisfactory results and improving the quality of life of cancer patients with ORN.
\end{abstract}

Keywords: Neoplasms; Radiotherapy; Osteoradionecrosis.

\section{Resumo}

Em relação ao tratamento das neoplasias de cabeça e pescoço, a osteorradionecrose (ORN) é a complicação tardia mais preocupante da radioterapia. É uma condição em que o osso irradiado se torna desvitalizado e exposto através de fístulas na pele ou mucosa, além de permanecer sem cicatrização por um período mínimo de três meses. Apesar de ser uma condição conhecida pelos profissionais que tratam essas neoplasias, se trata de uma doença muito controversa,

\footnotetext{
${ }^{1} \mathrm{MSc}$ in Sciences Pharmarceutical. State University of Bahia (UNEB), Bahia, Brazil

${ }^{2} \mathrm{PhD}$ in Human Pathology. Associate professor of PPGFARMA, State University of Bahia (UNEB), Bahia, Brazil

${ }^{3}$ Buccomaxillofacial Surgeon. Oral and Maxillofacial Surgery Department, Bahiana School of Medicine and Public Health (EBMSP), Bahia, Brazil

${ }^{4} \mathrm{PhD}$ student of the Pos Graduate Program in Interactive Processes of Organs and Systems in the Institute of Health Sciences of the Federal

University of Bahia (UFBA). Assistant professor of Bahiana School of Medicine and Public Health (EBMSP), Bahia, Brazil

${ }^{5} \mathrm{PhD}$ in Laser in Dentistry. Associate professor, Buccomaxillofacial Surgery Department, Bahiana School of Medicine and Public Health (EBMSP),

Bahia, Brazil

${ }^{6} \mathrm{PhD}$ in Human Pathology. Associate professor of Health Science Institute, Federal University of Bahia (UFBA), Bahia, Brazil
} 
desde sua classificação até o plano de tratamento mais adequado. Seus principais sinais e sintomas são dor, drenagem de secreção, fístulas, úlceras da mucosa oral, exposição óssea e necrose do osso e dos tecidos moles circundantes. Este estudo tem como objetivo relatar um caso clínico de paciente com ORN em mandíbula atendido na Escola Bahiana de Medicina e Saúde Pública e no Hospital Geral Roberto Santos. Paciente masculino, 60 anos, portador de neoplasia maligna em região amigdaliana, foi diagnosticado com ORN em mandíbula, três anos após radioterapia. Foi realizado tratamento conservador (ozonioterapia, oxigenação hiperbárica e enxaguante bucal com clorexidina) associado ao desbridamento cirúrgico, com resultados positivos através da reabilitação dos pacientes. Pode-se concluir que a associação de terapias conservadoras com a cirurgia demonstrou resultados satisfatórios, além de melhorar a qualidade de vida de pacientes oncológicos diagnosticados com ORN.

Palavras-chave: Neoplasias; Radioterapia; Osteorradionecrose.

\section{Resumen}

En cuanto al tratamiento de las neoplasias de cabeza y cuello, la osteorradionecrosis (ORN) es la complicación tardía de la radioterapia más preocupante. Es una condición en la que el hueso irradiado se desvitaliza y queda expuesto a través de fístulas en la piel o mucosas. Permanece sin curar durante un período de al menos tres meses. A pesar de ser una entidad conocida por los profesionales que tratan las neoplasias de cabeza y cuello, la enfermedad tiene muchas controversias, desde sus clasificaciones hasta su mejor plan de tratamiento. Sus principales signos y síntomas son dolor, drenaje de secreciones, fístulas, úlceras de la mucosa oral, exposición ósea, necrosis ósea y tejido blando circundante. Este estudio tiene como objetivo reportar un caso clínico de un paciente con ORN en la mandíbula atendido en la Facultad de Medicina y Salud Pública de Bahía y en el Hospital General Roberto Santos. Paciente masculino, 60 años, con neoplasia maligna en región amigdalina, diagnosticado de ORN en región mandibular, tres años después de la radioterapia. La propuesta de tratamiento fue conservadora (ozoterapia, oxígeno hiperbárico y colutorio con clorexidina) asociado al desbridamiento quirúrgico, con buenos resultados que implicó la rehabilitación de los pacientes. Se concluye que las regiones con dificultades de cicatrización acompañadas de destrucción ósea después de la radioterapia deben ser investigadas cuidadosamente para un buen pronóstico de la enfermedad.

Palabras clave: Neoplasias; Radioterapia; Osteoradionecrosis.

\section{Introduction}

Annually, more than eight million new cases of cancer occur worldwide. Oral cancer corresponds for more than 200,000 of these cases. Approximately $10 \%$ of malignant tumors are head and neck cancer, and $90 \%$ of which are squamous cell carcinoma (dos Santos, et al., 2015; INCA, 2019). Head and neck cancer can affect several sites, with an average of 40\% of cases occurring in the oral cavity, following $25 \%$ in the larynx, $15 \%$ in the pharynx, $7 \%$ in the salivary glands, and $13 \%$ in other regions. Currently, the recommended treatment for these neoplasms is surgery associated or not with radiotherapy (RT) and chemotherapy (Ministério da Saúde, 2014; Store \& Larheim, 1999). Despite the favorable results obtained with RT, late complications from this treatment may result in a decrease in the patients' quality of life. At the same time, it might increase treatment morbidity (Aldunate, et al., 2010; Amorim, 2016; Ministério da Saúde, 2014; Raber-Durlacher, et al., 2010; Store \& Larheim, 1999).

The RT destroys neoplastic cells, but it also affects healthy tissues damaging their genetic material, which is essential for cell division and stability (Aldunate, et al., 2010; Amorim, 2016; Ministério da Saúde, 2014; Raber-Durlacher, et al., 2010). Complication of RT might include xerostomia, mucositis, candidiasis, osteoradionecrosis (ORN), dysphagia, dysgeusia, ageusia, opportunistic infections, periodontitis, and trismus (dos Santos, et al., 2015; Ribeiro, et al., 2018). Most ORN cases occur in the first three years after RT. The mandible is more affected than the maxilla due its bone density. Also, the lower jaw receives larger volume of radiation doses (Aldunate, et al., 2010; He, et al., 2015). Most affected areas are the angle and the mandibular body, since their blood supply comes exclusively from the lower alveolar artery, making these areas more dependent on the periosteal blood supplies (dos Santos, et al., 2015; Epstein, et al., 1997; He, et al., 2015; Ribeiro, et al., 2018).

The ORN was first described in 1926. It was first known as radiation osteitis by Ewing, the first researcher to record the bone changes caused by RT (Epstein, et al., 1997; He, et al., 2015; Ribeiro, et al., 2018). ORN is a potentially debilitating disease clinically presented as persistent pain and chronic bone exposure. The radiation therapy causes loss of bone tissue integrity, remaining without healing for more than three months, in the absence of a local tumor, recurrence, or metastatic 
disease (dos Santos, et al., 2015; He, et al., 2015; INCA, 2019; Ribeiro, et al., 2018). Also, it is commonly associated with local infection, which can lead to orocutaneous fistulae, and pathological fracture (He, et al., 2015; Ribeiro, et al., 2018).

Many factors have been suggested to develop ORN, such as delivered radiation, malnutrition, health condition, oral hygiene, and trauma, such as dental extraction and periodontal disease. It can also spontaneously occur after RT with doses that exceed 60Gy (Gray) (Aldunate, et al., 2010; Amorim, 2016; dos Santos, et al., 2015; Ministério da Saúde, 2014; Ribeiro, et al., 2018). The mean age of affected patients is 50 years, and the prevalence ratio between sexes is 1.6:1 for males (Aldunate, et al., 2010; dos Santos, et al., 2015). Signs and symptoms of ORN can be varied. The most common clinical features for diagnosing ORN are local pain, trismus, halitosis, bone exposure, fistulas, drainage of secretion, and fistulization to the skin or mucosa, without tumor recurrence. However, many cases are asymptomatic, and the diagnosis occurs through imaging exam (Aldunate, et al., 2010; Epstein, et al., 1997; He, et al., 2015; Ribeiro, et al., 2018).

Initially, it was believed that the ORN pathophysiology was related from the relationship between radiation, trauma, and infection. According to Marx (1983), the "3H principle" could explain the effect of radiation in bone tissues. The radiation would cause hypoxia, hypovascularity, and hypocellularity of tissue, thus inhibiting substitution of conjunctive tissue and of cells to complete the turnover for the maintenance of homeostasis and wound cicatrization., leading consequently to bone exposure (Aldunate, et al., 2010; Amorim, 2016; dos Santos, et al., 2015; Ribeiro, et al., 2018). Also, the author noted that ORN is not a primary infection of the irradiated bone. But that the metabolic and homeostatic alteration of the irradiated is responsible for persistent hypoxia that causes chronic injury. Such imbalance between synthesis and tissue degradation generates progressive hyalinization and fibrosis of the medullary spaces, leading to the development of fibrotic scar tissue. (Aldunate, et al., 2010; Ribeiro, et al., 2018; Martos-Fernández, et al., 2018). Such vascular dysfunctions help to promote the initial pre-fibrotic phase, which is intensified due to the presence of oxygen free radicals produced by radiation. Consequently, cause a dysregulation of fibroblast proliferation and metabolism (Martos-Fernández, et al., 2018; Zhang, et al., 2020).

This study aims to report a case of a patient diagnosed with ORN in the lower jaw. It discusses concepts about the disease, diagnosis, characteristics, and therapeutic modalities. This case report has considerable social and clinical relevance because affected patients need besides aesthetic-functional rehabilitation also the reinsertion in regular social life.

\section{Methodology}

This is a clinical case report. A 60 year-old- male patient sought care from the OralMaxillofacial Surgery and Traumatology team at the Stomatology Clinic of Bahiana School of Medicine and Public Health (EBMSP), in Salvador, Bahia, Brazil. He presented a chief complaint of a pain in the body region of the lower jaw. In 2010, he was diagnosed with malignant neoplasm in the tonsil region (T2N1M0), through a biopsy performed at Dom Pedro de Alcântara Hospital in Feira de Santana (BA). As a treatment, he underwent head and neck RT and chemotherapy.

The patient was referred for dental treatment, and five extractions were performed. He followed up with an oncologist until 2015 when he was discharged. In consultation with a professional, the patient was clinically diagnosed with ORN and then referred to the Dentistry Course of the EBMSP, in 2017. The patient denied alcoholism, smoking, drug abyse, and systemic diseases. Informed patient consent form was presented signed by the patient.

\subsection{Physical examination and Imaging Exams}

Extra oral examination showed an edema in left side of the middle third of the face. Patient referred pain in the left mandibular body region, limited mouth opening, poor oral hygiene, presence of bone exposure in the submental and submandibular region on the left side of the face (Figure 1) and also in the oral mucosa (Figure 2). In the intraoral examination, the presence of calculus was observed in dental surfaces, partial edentulism, gingival recessions, cervical teeth lesions, 
destruction of the mandible cortex, and exposed necrotic bone through a fistula in the bottom of the mandibular vestibule.

A panoramic radiography (Figure 3) showed a radiolucent bilateral area in the mandible body. Also, it was observed a horizontal and vertical bone loss in the mandible, which represents a serious picture of injury compatible with bone necrosis. Computed tomography exhibited disruption of bone cortical in the mandibular body, bilaterally. Diagnosis of ORN was made and patient instituted conservative measures of treatment. He was classified, according to Epstein et al. (1997), as a Stage III-B ORN.

Figure 1: A: Extra oral exam, front view; B: Right side view; C: Submental region with bone exposure; D: Left lateral view, with exposed bone.

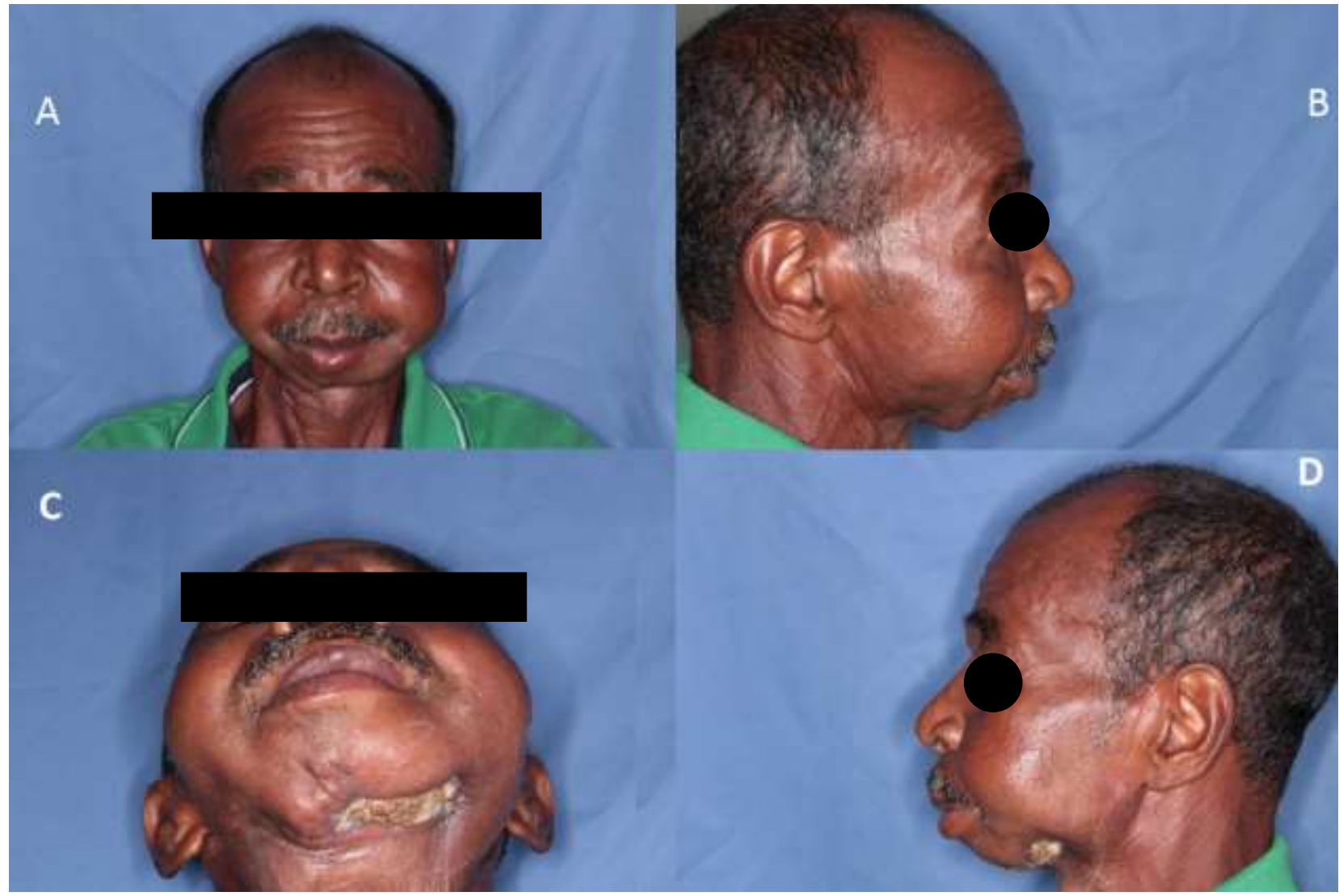

Source: Authors.

Figure 2: Cervical lesions in multiple teeth and bone exposure bilaterally.

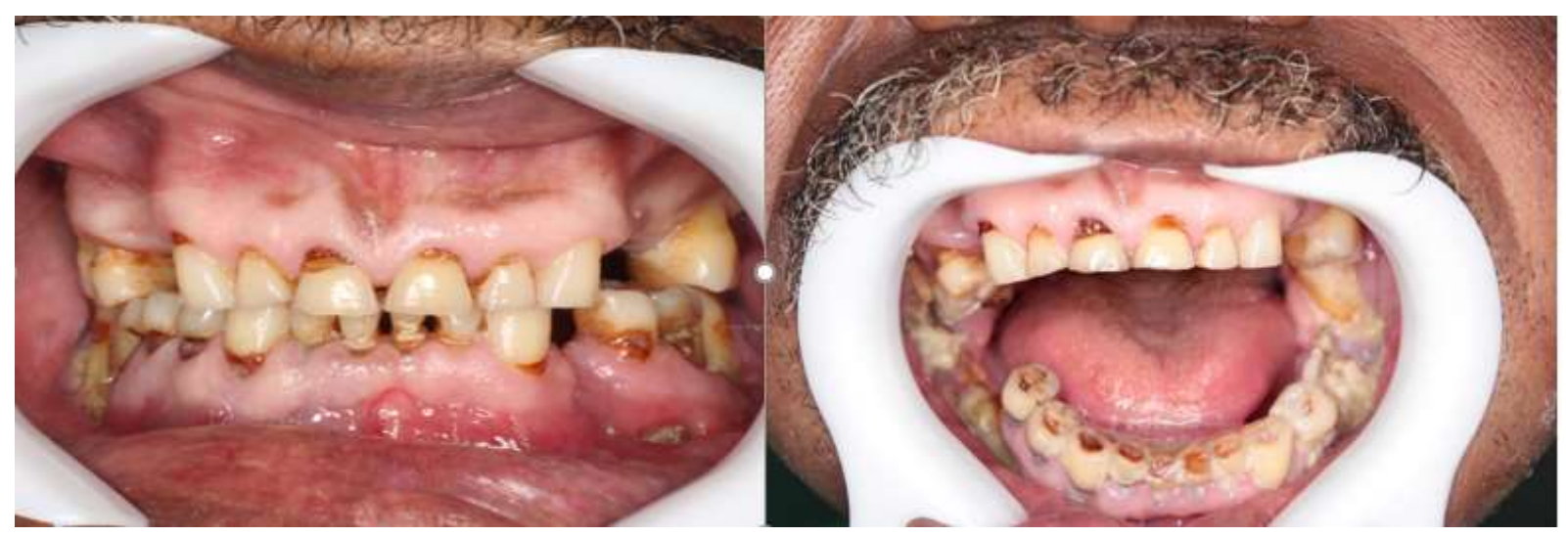

Source: Authors. 
Figure 3: Panoramic radiographic with vertical and horizontal bone loss in the mandibular body region, bilaterally.

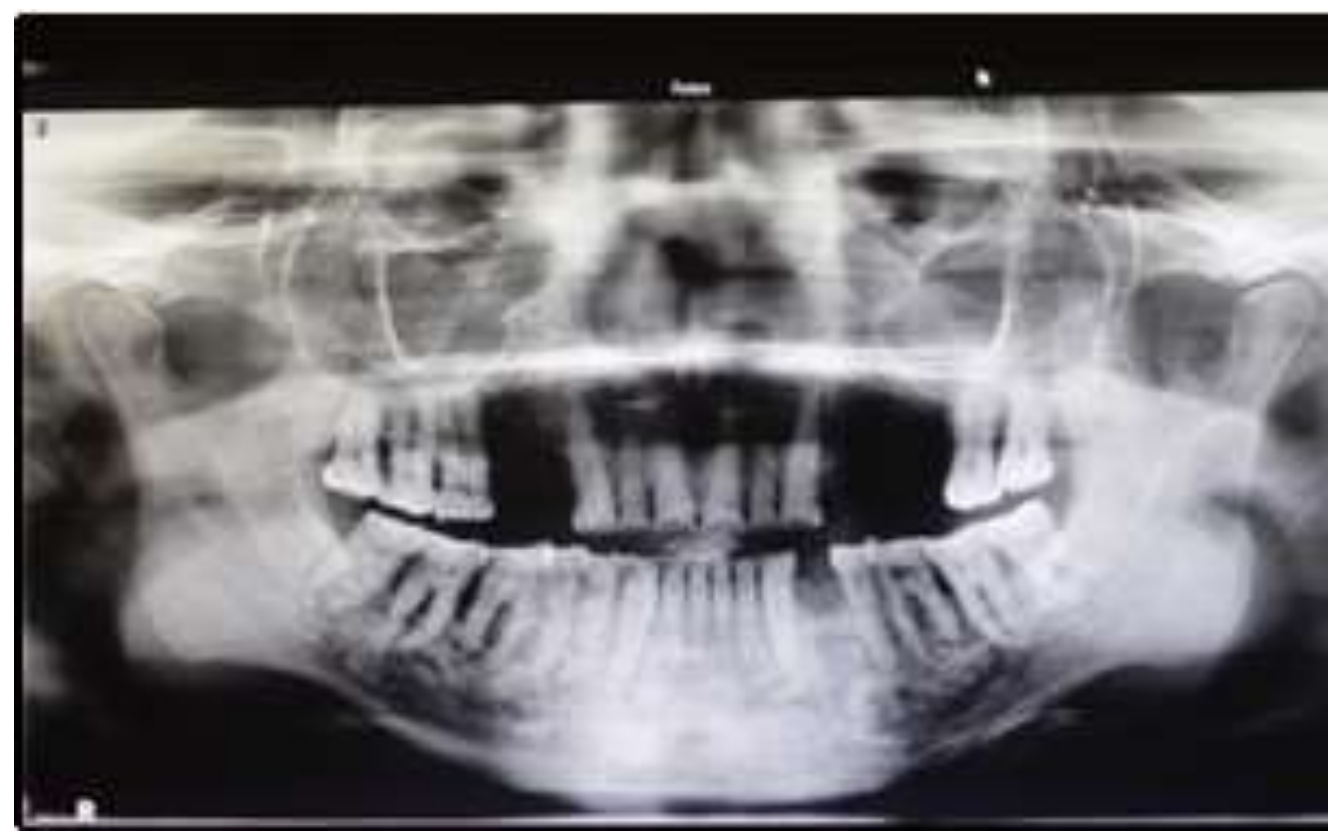

Source: Authors.

\subsection{Treatment}

In 2017, the patient underwent twelve sessions of ozone therapy. In addition, the patient had undergone ten hyperbaric oxygen therapy sessions. Dental treatment was also realized as a pre-surgical protocol.

The surgery was planned with the aid of a biomodel (Figure 4) using a 3D printer with images of the patient's face from the computed tomography. The first surgical procedure took place at General Roberto Santos Hospital. Through bilateral submandibular access with extension and midline joint, the mandible was partially removed. The surgical specimen (Figure 5) was stored in a $10 \%$ formaldehyde container and sent to EBMSP for anatomopathological examination. Surgical debridement of devitalized soft tissue or signs of low vitality was performed. After this process, the $2.4 \mathrm{~mm}$ system reconstruction plate was adapted and fixed to the remnant bone of the mandible. After the surgical approach, the patient was referred for an imaging exam for postoperative control (Figure 6).

Figure 4: Biomodel used for modeling the $2.4 \mathrm{~mm}$ system reconstruction plate.

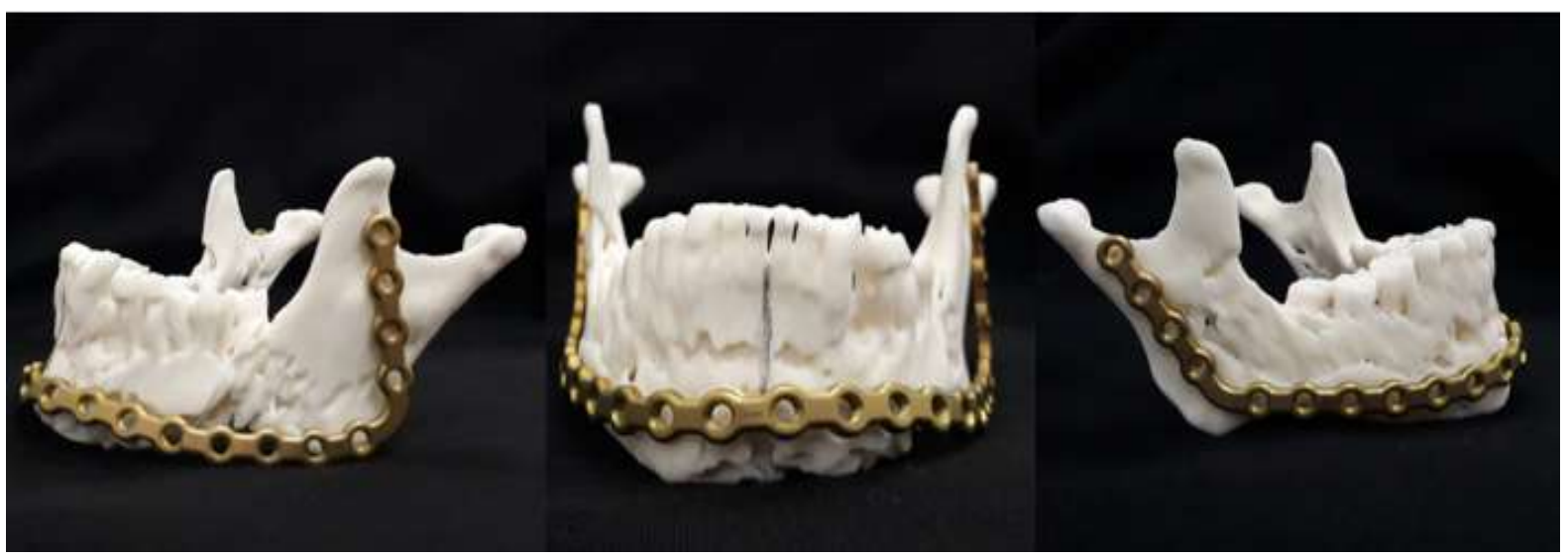

Source: Authors. 
Research, Society and Development, v. 10, n. 11, e181101119632, 2021

(CC BY 4.0) | ISSN 2525-3409 | DOI: http://dx.doi.org/10.33448/rsd-v10i11.19632

Figure 5: Mandible removed during the first surgical procedure for anatomopathological study.

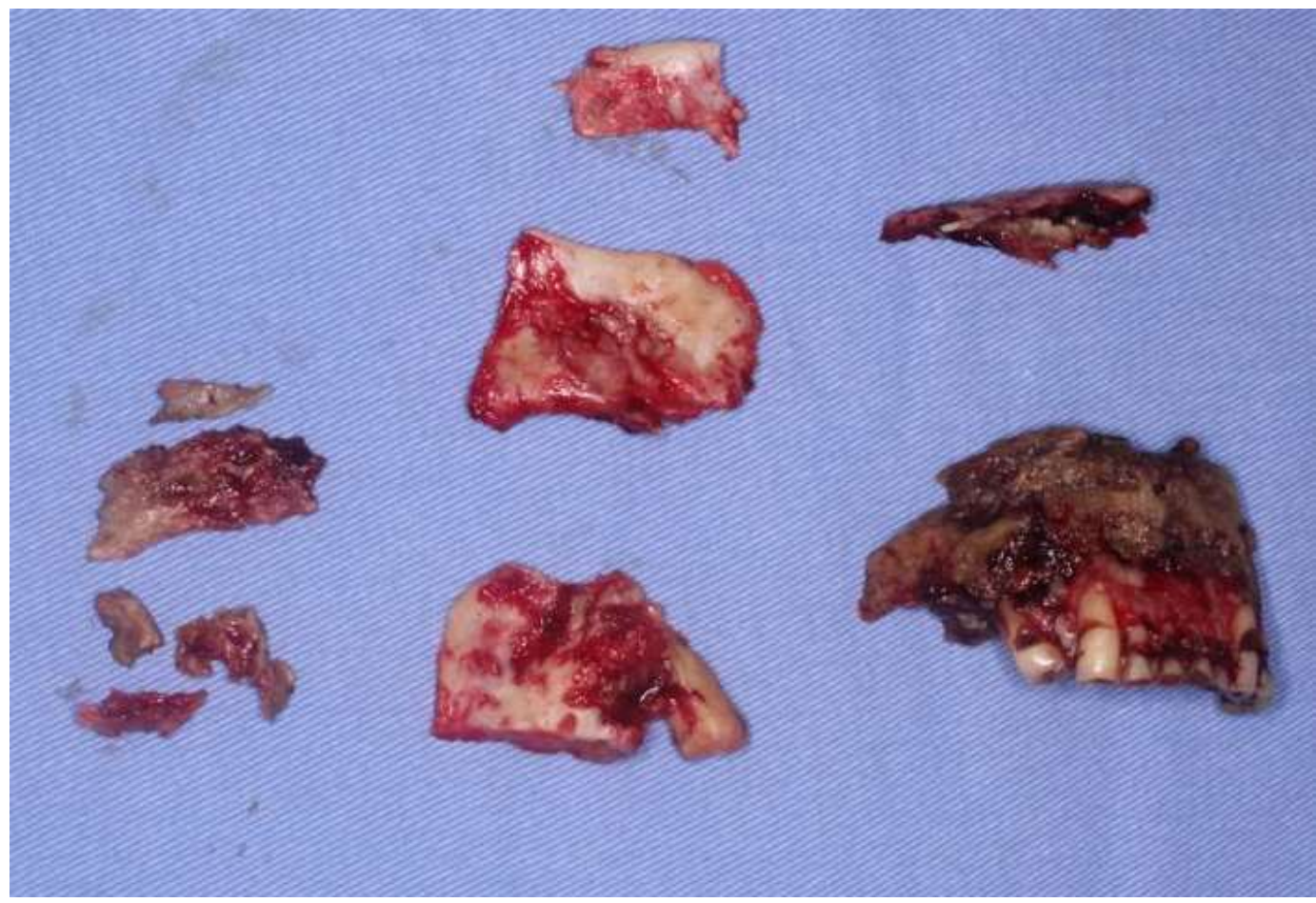

Source: Authors.

Figure 6: 3D reconstruction of the face tomography, showing adaptation of the $2.4 \mathrm{~mm}$ system reconstruction plate.

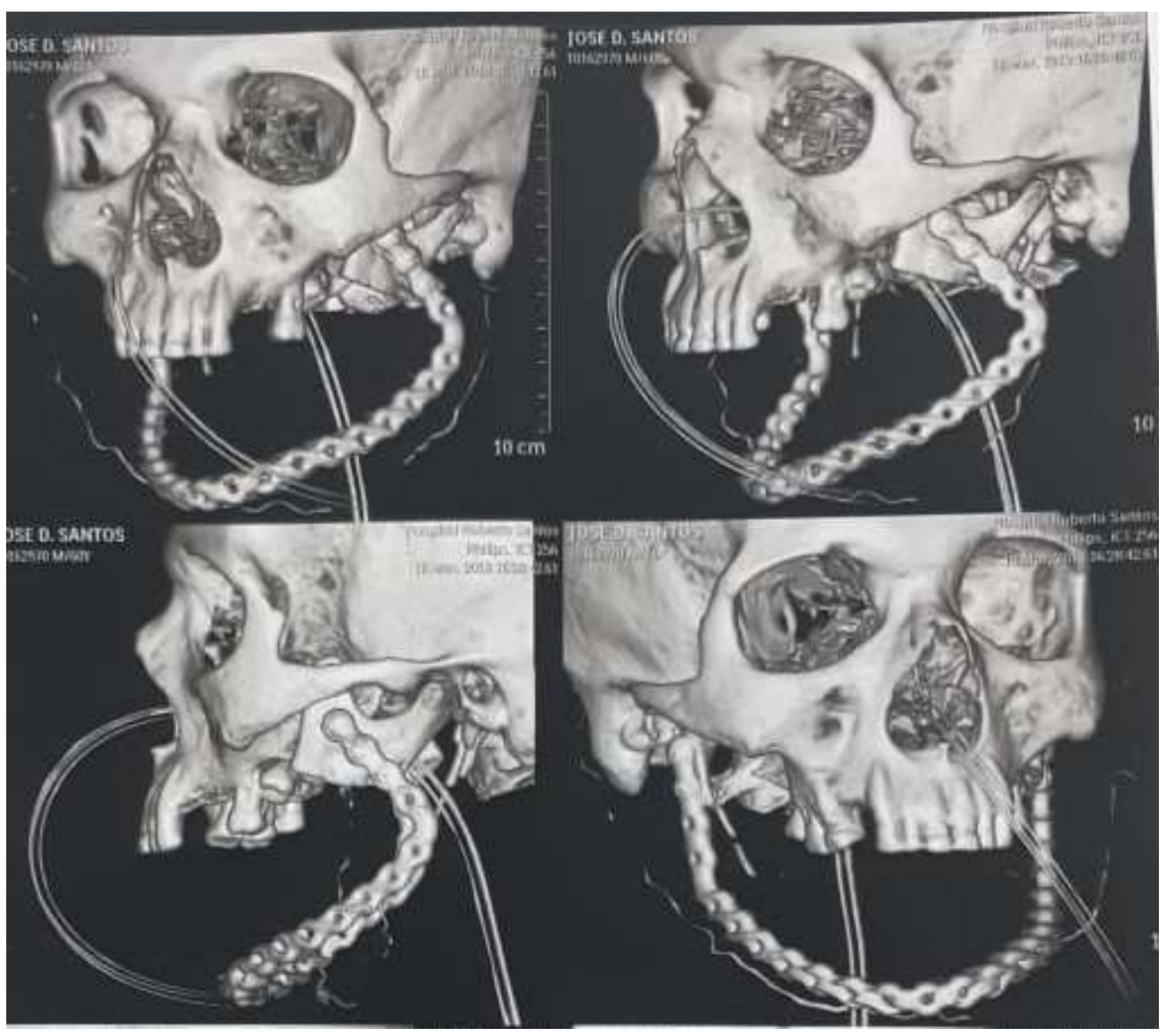

Source: Authors. 
There were persistence and progression of the preexisting local infection in the post-surgical period. The remaining tissue surrounding the surgical access site underwent a process of necrosis (Figure 7-A). The patient underwent a second surgery nine days later of the first surgical procedure. A culture examination and antibiogram of a persistent purulent secretion at the surgical site revealed the following microorganisms: Escherichia coli, Pseudomonas aeruginosa, Klebsiella pneumoniae spp pneumoniae. The second surgical procedure consisted in removing the synthesis material and four screws from the $2.4 \mathrm{~mm}$ system. The material was infected and exposed due to the loss of surrounding tissue vitality. Bilateral Temporomandibular Joint (TMJ) disarticulation and new wound debridement were also performed in this same procedure. After, the patient stayed monitored at the hospital level with a speech therapist, physiotherapist, psychologist, and nutritionist.

After the second surgical procedure, the patient evolved with an improvement in the infection, using a nasoenteral tube for feeding, with spontaneous breathing via tracheostomy, and without pain complaints in the surgical access region. We continued the treatment through daily monitoring with the oral maxillofacial team, which changed the dressing twice a day and oral hygiene with aqueous chlorhexidine 3 times a day. After clinical improvement, the patient evolved with difficulty in accepting an oral diet. A gastrostomy procedure was needed to ensure a better nutritional condition for the patient. To date, the patient (Figure 7-B) is being followed up with the oral maxillofacial team at the EBMSP. He underwent a panoramic radiographic (Figure 8) of post-control operative and received the result of the anatomopathological exam, which was conclusive for ORN.

Figure 7: A: Left side, showing dehiscence in the suture and presence of purulent secretion; B: Patient in the 11th postoperative month, here we observe lower lip ptosis.
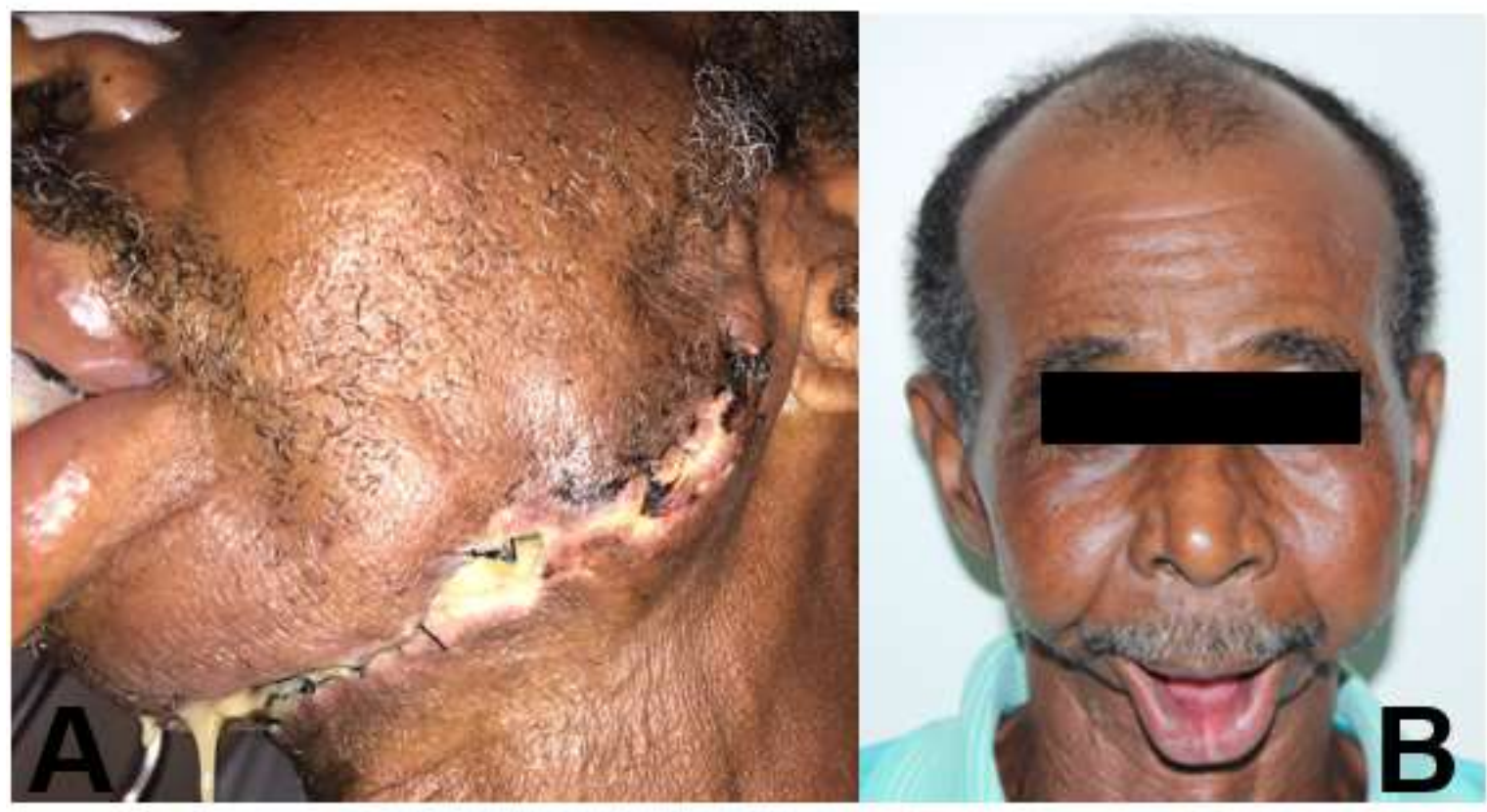

Source: Authors. 
Figure 8: Panoramic radiography after hospital discharge, showing absence of synthesis material and TMJ disarticulation.

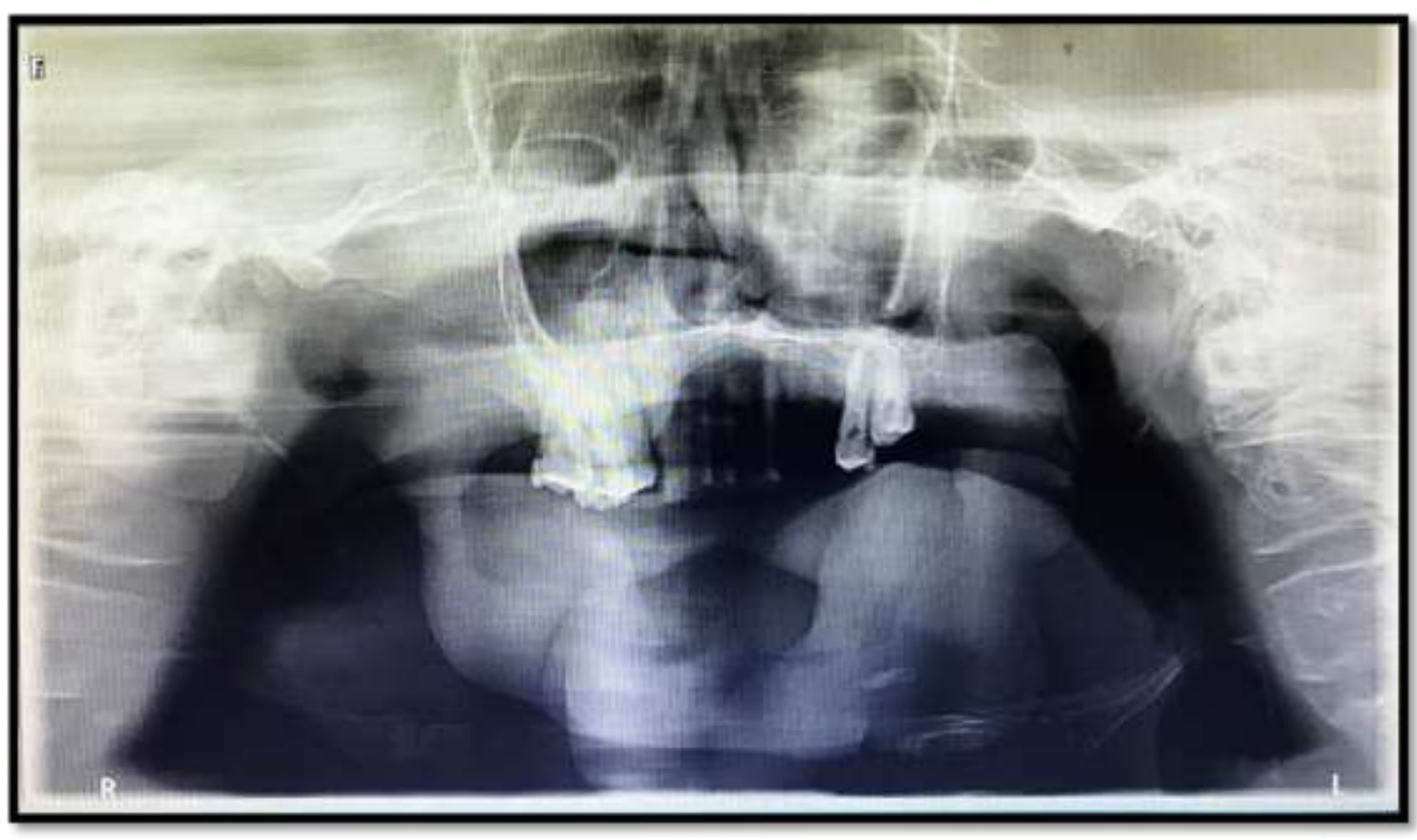

Source: Authors.

\section{Results and Discussion}

Patients undergoing radiotherapy alone or as part of the treatment of head and neck cancer are likely to develop osteoradionecrosis. (Epstein, et al., 1997; Martos-Fernández, et al., 2018; Marx, 1983). The patient must be accompanied by a multidisciplinary team before, during and after RT, to minimize the possible adverse effects. The dentist has an important role in the prevention of ORN, since oral health must be carefully performed to minimize the chances of late complications (Marx, 1983; Ribeiro, et al., 2018). In the present case, the patient reported dental follow-up during the pre-RT period, which contributed to a late diagnosis.

ORN signs and symptoms can range from local pain to bone exposure, sometimes also occurring a pathological fracture (Aldunate, et al., 2010; Amorim, 2016; Ribeiro, et al., 2018). The patient of the present case corroborates with the literature clinical characteristic of ORN. We observed pain, trismus, halitosis, bone exposure with fistula in the oral mucosa and skin, and drainage of purulent secretion.

There is a controversy about the ideal therapy for ORN (Dantas \& Reis, 2019). However, it is widely accepted that the treatment should be based on a multi-professional approach and mostly, conservative. For initial cases, it is recommended mouthwashes with chlorhexidine and analgesics prescription. It is also necessary the adequacy of oral hygiene and the cessation of some nocive habits such as the use of tobacco and alcohol abuse. Both are irritating factors to the oral mucosa (Aldunate, et al., 2010; Amorim, 2016; Dantas \& Reis, 2019; Moraes, et al., 2016). In advanced cases, invasive techniques such as the surgical approach - resection of the affected bone segment - is needed. (Dantas \& Reis, 2019; Oliveira, et al., 2021). The present patient denied alcohol and tobacco abuse. He had undergone oral environment adequacy protocol before the surgical procedure. It was also performed as an adjunctive treatment with ozone therapy and hyperbaric oxygenation.

Ozone therapy aims to inactivate microorganisms, stimulate oxygen metabolism, and activate the immune system (Anzolin \& Bertol, 2018; Moraes, et al., 2016; Oliveira, et al., 2021). Besides, this therapy also acts in the control of symptoms, as evidenced in the present case where the patient reported a decrease in the constant pain he felt in the left mandibular region. Compared to hyperbaric oxygen, ozone has better long-term results and is a less costly therapeutic 
modality. Both modalities promote an improvement in symptoms, in addition to stimulating the healing process (Dantas \& Reis, 2019; Moraes, et al., 2016).

Several factors are associated with the development of ORN, such as high doses of RT, malnutrition, health condition, oral hygiene and trauma (Aldunate, et al., 2010; dos Santos, et al., 2015; Ribeiro, et al., 2018). In the present case, ORN probably developed due to a set of factors. Poor oral hygiene, surgical trauma, periodontal disease, extensive caries and the radiation played a role in developing the patient's condition.

The mandible is a bone of great importance in facial harmony, contributing to chewing, swallowing, support of the base of the tongue and articulates with the base of the skull (Caparrotti, et al., 2017 For the present case, the mimicry of the mandibular arch was planned, which favors the maintenance of facial aesthetics. In addition, it also helps in the social reinsertion of the patient. In addition, it fixes the suprahyoid muscles in the anterior region of the $2.4 \mathrm{~mm}$ system reconstruction plate, aiming at a better prognosis regarding the phonation capacity and swallowing of the patient.

Suture dehiscence occurred due to the low tissue vitality and the internal compression exerted by the postoperative edema. That led to a consequent exposure of the synthesis material and, consequently, its removal. This procedure led to a loss of the ability to articulate the TMJ and to support the suprahyoid muscles. As a consequence, the patient lost swallowing capacity (Raz, et al., 2017). Therefore, to ensure a better nutritional intake, a gastrostomy was performed before hospital discharge, since the patient's swallowing capacity was unsatisfactory given the need for food.

The exacerbation of the infectious process after the first surgical procedure occurred due to low tissue vitality and reduced vascularization in the soft tissues, due to radiation (Caparrotti, et al., 2017; Raz, et al., 2017). To improve vascularization, we performed surgical debridement. Debridement consists of removing dead, devitalized, or contaminated tissues and also any foreign body located in the wound. This procedure reduces the number of microorganisms, toxins, and other substances. It also stimulates bleeding, increases the local blood supply, revives the tissue, inducing the appearance of defense cells, improving nutrition for the region, and finally resulting in better local conditions for tissue healing (Moraes, et al., 2016). Our patient had a communication with the extra-oral environment after the second surgical procedure, which shows the difficulty in healing poorly vitalized tissues.

ORN is a multifactorial condition, which can be developed spontaneously or from some trauma (Aldunate, et al., 2010). There is a debate between the risk of developing ORN and the time elapsed since the end of RT. These effects caused by radiation are progressive over time, and the individual may develop ORN for up to three years after the end of the RT (Aldunate, et al., 2010; Martos-Fernández, et al., 2018; Ribeiro, et al., 2018). The patient completed RT in 2014 and was diagnosed with ORN three years later. This justifies the need for long-term follow-up of patients undergoing RT.

Despite being an entity well known by health professionals who deal with the treatment of head and neck cancer, ORN presents many controversies. From its classification to its best therapeutic (He, et al., 2015; Lyons, et al., 2014; Karagozoglu, et al., 2014). For initial lesions, conservative management can be used. For advanced cases, radical resection followed by reconstruction might be necessary. It is imperative to adapt the oral environment before RT, as well as to maintain oral health care during and after treatment. Carry out drug control in the initial periods of treatment and, if the ORN is installed, prevent the progression of the disease. Drug treatment, hyperbaric therapy measures to control the symptoms. In some cases, surgical intervention may be needed (Dantas \& Reis, 2019). In the present case, the association of hyperbaric oxygen, ozone therapy, antibiotic therapy, and surgical intervention were effective in treating this disease.

Therefore, it is of great importance that professionals involved in the rehabilitation of irradiated patients be aware of any new clinical signs of injury recurrence, as these patients are contraindicated to perform any surgical procedure due to little or no vascularization of the site, which results in difficulty in the healing process of the surgical wound and later ORN. 


\section{Conclusion}

ORN is a serious late complication of RT, which can have poor prognosis. The association of conservative therapies with surgery demonstrated satisfactory results and improving patient's quality of life.

The identification of an optimal protocol with a view to obtain better results for the prevention and control of ORN should be the primary objective of health professionals who assist patients with head and neck cancer. More controlled and randomized studies are necessary to confirm this statement definitively.

\section{References}

Anzolin, A. P., \& Bertol, C. D. (2018). Ozone therapy as an integrating therapeutic in osteoartrosis treatment: a systematic review. BrJP, 1(2), 171-175. https://www.scielo.br/j/brjp/a/yMmx8KdmxqkTfjx4f77Xhwx/?lang=pt\&format=pdf

Aldunate, J. L. C. B., Coltro, P. S., Busnardo, F. D. F., \& Ferreira, M. C. (2010). Osteorradionecrose em face: fisiopatologia, diagnóstico e tratamento. Revista Brasileira de Cirurgia Plástica, 381-387. http://www.rbcp.org.br/details/604/pt-BR/osteorradionecrose-em-face--fisiopatologia--diagnostico-e-tratamento

Amorim, W. D. (2016). Manejo de osteorradionecrose em pacientes oncológicos. [Monografia].

Brasil, Ministério da Saúde. (2014). Manual de Bases Técnicas da Oncologia-SIA/SUS-Sistema de Informações Ambulatoriais. https://www.inca.gov.br/sites/ufu.sti.inca.local/files//media/document//manual-oncologia-26a-edicao.pdf

Caparrotti, F., Huang, S. H., Lu, L., Bratman, S.V., Ringash, J., Bayley, A., Cho, J., Giuliani, M., Kim, J., \& Waldron, J. (2017). Osteoradionecrosis of the mandible in patients with oropharyngeal carcinoma treated with intensity-modulated radiotherapy. Cancer, 123(19), 3691-3700. 10.1002/cncr.30803.

Dantas, J. B. L., \& Reis, J. V. N. A. (2019). New therapeutic approaches to osteoradionecrosis: Literature Review. Journal of Health Sciences, 21(3), 243-9. http://dx.doi.org/10.17921/2447-8938.2019v21n3p243-249

dos Santos, R., kuhn Dall'Magro, A., Giacobbo, J., Lauxen, J. R., \& Dall'Magro, E. (2015). Osteorradionecrose em pacientes submetidos à radioterapia de cabeça e pescoço: relato de caso. Revista da Faculdade de Odontologia-UPF, 20(2), 232-37. https://doi.org/10.5335/rfo.v20i2.4497

Epstein, J., Van der Meij, E., McKenzie, M., Wong, F., Lepawsky, M., \& Stevenson-Moore, P. (1997). Postradiation osteonecrosis of the mandible: a longterm follow-up study. Oral Surgery, Oral Medicine, Oral Pathology, Oral Radiology, and Endodontology, 83(6), 657-662. 10.1016/s1079-2104(97)90314-0

He, Y., Liu, Z., Tian, Z., Dai, T., Qiu, W., \& Zhang, Z. (2015). Retrospective analysis of osteoradionecrosis of the mandible: proposing a novel clinical classification and staging system. International Journal of Oral Maxillofacial Surgery, 44(12), 1547-57. 10.1016/j.ijom.2015.04.006

Instituto Nacional de Câncer José Alencar Gomes da Silva. (2019). Estimativa 2020: incidência de câncer no Brasil. Rio de Janeiro: INCA. https://www.inca.gov.br/publicacoes/livros/estimativa-2020-incidencia-de-cancer-no-brasil

Karagozoglu, K. H., Dekker, H. A., Rietveld, D., de Bree, R., Schulten, E. A. J. M., \& Kantola, S. (2014). Proposal for a new staging system for osteoradionecrosis of the mandible. Med Oral, Pat Oral and Cir Bucal, 1(19), 433-7. 10.4317/medoral.19623

Lyons, A., Osher, J., Warner, E., Kumar, R., \& Brennan, P. (2014). Osteoradionecrosis - A review of current concepts in defining the extent of the disease and a new classification proposal. Brazilian Journal Oral Maxillofacial Surgery, 52, 392-395. 10.1016/j.bjoms.2014.02.017

Martos-Fernández, M., Saez-Barba, M., López-López, J., Estrugo-Devesa, A., Balibrea-del-Castillo, J. M., \& Bescós-Atín, C. (2018). Pentoxifylline, tocopherol, and clodronate for the treatment of mandibular osteoradionecrosis: a systematic review. Oral Surgery, Oral medicine, Oral Pathology and Oral Radiology, 125(5), 431-439. 10.1016/j.0000.2018.02.004

Marx, R. E. (1983). Osteoradionecrosis: a new concept of its pathophysiology. Journal of Oral and Maxillofacial Surgery, 41(5), 283-288. 10.1016/02782391(83)90294-X

Moraes, P. D. C., Thomaz, L. A., Silva, M. B. F., Junqueira, J. L. C., \& Teixeira, R. G. (2016). Successful in a conservative treatment of osteoradionecrosis of the jaw: a case report and review of literature. RGO-Revista Gaúcha de Odontologia, 64(2), 212-218. https://doi.org/10.1590/1981-863720160002000143190

Oliveira, C. C. B., Dantas, J. B. L., Borges, D. P. O., Martins, G. B., Medrado, A. R. A. P., Reis, J. V. N. A., \& Marchionni, A. M. T. (2021). Ozonotherapy for Treatment of Radiation Therapy-induced Jaw Osteonecrosis and Bisphosphonates: Case Report. Revista Brasileira de Cancerologia, 67(2), e-02785. https://doi.org/10.32635/2176-9745.RBC.2021v67n2.785

Raber-Durlacher, J. E., Elad, S., \& Barash, A. (2010). Oral Mucositis. Oral Oncology, 46(6), 452-6. 10.1016/j.oraloncology.2010.03.012

Raz, D. J., Clancy, S. L., \& Erhunmwunsee, L. J. (2017). Surgical management of the radiated chest wall and its complications. Thoracic Surgery Clinics, 27(2), 171-179. 10.1016/j.thorsurg.2017.01.011

Ribeiro, G. H., Chrun, E. S., Dutra, K. L., Daniel, F. I., \& Grando, L. J. (2018). Osteonecrosis of the jaws: a review and update in etiology and treatment. Brazilian Journal of Otorhinolaryngology, 84(1), 102-108. https://doi.org/10.1016/j.bjorl.2017.05.008

Store, G., \& Larheim, T. (1999). Mandibular osteoradionecrosis: a comparison of computed tomography with panoramic radiography. Dentomaxillofacial Radiology, 28(5), 295-300. 10.1038/sj/dmfr/4600461 
Research, Society and Development, v. 10, n. 11, e181101119632, 2021

(CC BY 4.0) | ISSN 2525-3409 | DOI: http://dx.doi.org/10.33448/rsd-v10i11.19632

Zhang, Z., Xiao, W., Jia, J., Chen, Y., Zong, C., Zhao, L., \& Tian, L. (2020). The effect of combined application of pentoxifylline and vitamin E for the treatment of osteoradionecrosis of the jaws: a meta-analysis. Oral Surgery, Oral medicine, Oral Pathology and Oral Radiology, 129(3), $207-214$. 10.1016/j.0ooo.2019.08.005 